\title{
Online Social Gathering Service Firm Strategy
}

\author{
Chusnul Rofiah ${ }^{1^{*}}$
}

${ }^{1}$ STIE PGRI Dewantara

\section{Article Information}

History of article:

Received April 2021

Approved September 2021

Published October 2021

\begin{abstract}
This research is written on the background of how the strategy to market online social gathering services is behind the rise of online social gathering scams. With the postpositivist paradigm of a qualitative approach to case study design, it has been found that the marketing strategy for online social gathering services will survive if it is supported by the products offered, causing reactions and consumer interest to be noticed, owned, used or consumed so as to satisfy consumer wants and needs. The products offered by the owner to consumers also vary. The price offered by the owner of this online social gathering is in accordance with the get that consumers want to get, so that consumers choose the get the social gathering slot according to their wishes, the use of online media is more effective to reach wider consumers and offer their products. The owner of this online social gathering benefits in the form of having a relationship with many people and also benefits from holding an online social gathering, the most important finding of this research is to include the mandate in running an online social gathering service business.
\end{abstract}

Keywords: Online Social Gathering, Service Marketing, Service Marketing Strategy, Online Social Gathering Fraud

JEL Classificiation Code: M31, L1, O14 


\section{INTRODUCTION}

Online social gathering products that are familiar to the public. Meanwhile, the increasingly sharp competition must be accompanied by good management in order to survive in the industrial economy. Arisan is a term to simplify a financial regulation called Rotating Savings and Credit Associations (ROSCAs), which is an activity carried out by a group of people by holding an association within a certain period or period by collecting a certain amount of money or goods and then making a drawing, The draw aims to determine the participants winners who are entitled to a social gathering. The arisan is a conventional social gathering. Currently there are various types of arisan including regular social gathering, fall social gathering, and online arisan (Kharisma et al., 2020).

Online social gathering is a social gathering that is conducted through online media. Different from other types of arisan, online social gathering uses online technology in the form of smartphones or computers and the internet. The parties involved in the online arisan are the owner as the manager and the participants. The online social gathering system usually uses a knockout system. Online arisan does not require a meeting between the manager and its members in person. All transactions are carried out online (Yudha dan Rudy, 2015). Arisan is a fact in people's life. Arisan has become an informal financial institution and a means of community investment to avoid inflation in the price of necessities (Ramadhita dan Khoiriyah, 2020). Arisan can also be used as a means of education for the community in various fields, in other words, arisan is a way for someone to fulfill their daily needs in a light and easy way (Sarmalina et al., 2019). One of the factors that must be considered by online arisan owners in order to continue to exist is by developing a marketing strategy and improving service quality by providing a variety of products according to the needs and desires of consumers (Yusanto, 2002). There are several objects that are often used as material for social gathering. For example motor vehicles, (Susila, 2015), gold (Ria, 2019), household appliances, electronic equipment (Masithah, 2018), business capital or celebration (Khoiriyah, 2018) or house construction (Umar, 2017). The practice of arisan is also used for the purpose of carrying out worship, such as qurban animal arisan (Pribadi, 2020), Umrah and Hajj (Badriyah, 2015).

Even so, online social gathering is evidence of one of the positive impacts of the use of the internet and gadgets, but it also has a negative impact, namely the existence of online arisan fraud. The absence of direct meetings between managers and participants provides an opportunity for criminal acts to occur. Criminal acts that often occur in connection with online arisan are criminal acts of fraud. Online fraud committed by someone in this arisan activity is clearly detrimental to many parties. The obstacle currently occurring is that there is difficulty in proving it. Weak regulatory systems in enforcing the law on online social gathering fraud have resulted in online fraud cases occurring. Another obstacle is that the government is still unable and difficult to track down sites that lead to fraud. So that to minimize cases of arisan fraud in online media is very difficult to do. Enforcement of the law in cyberspace must continue to be made so that online fraud perpetrators can be held accountable for their actions (Mukarromah, 2021).

The definition of social gathering is an activity of collecting money or goods of the same value by several people and then drawn between them to determine who gets it, the lottery is held in a regular meeting until all members get it (https://kbbi. web.id/social gathering , 2021). According to Kotler and Kotler, (2012) states that marketing is a process in which companies establish strong relationships with customers and create value for customers, with 
the aim of obtaining customer satisfaction values in return. The marketing strategy is the basis for which the company plans to develop a sustainable competitive advantage through the market to be entered and the marketing program that is carried out to serve the target market (Tjiptono, 2008).

According to Alma, (1998) Service Marketing is any act of service is an act that can be offered by a party to another party which is basically intangible (intangible) and does not result in ownership of something. Market segmentation according to Tjiptono and Chandra, (2012) doing market segmentation, targeting, and positioning is placing a product or brand in the minds of consumers so that the product or brand has a distinctive or sustainable competitive advantage. Based on the above background, the author feels the need to study and research related marketing strategies for online social gathering services even though many people already know that online-based social gathering fraud is very prone?

\section{METHODOLOGY}

This study uses a postpositivist paradigm with a qualitative approach and a case study research design. A case study according to Yin, (2013) is an empirical inquiry that investigates phenomena in the context of real life, when the boundaries between the phenomenon and the context are not clearly visible and where multiple sources of evidence are utilized. Solutions That Keep Simple Qualitative Research Can be compiled without having carry on long-winded discussions but can still be accounted for, then we modify the model from a simple design Bungin, (2020:3-4) with simple design model with theory triangulation / simple research design with triangulation theory (Rofiah, 2021).

There are 7 main steps : (1). Sosial context and research question (2). Literature review (3). Research method and data collection (4). Data analysis (5). Draft Reporting (6). Triangulasi Theory (7). Reporting \& Findings. This research was conducted in Jombang Regency, East Java, to be

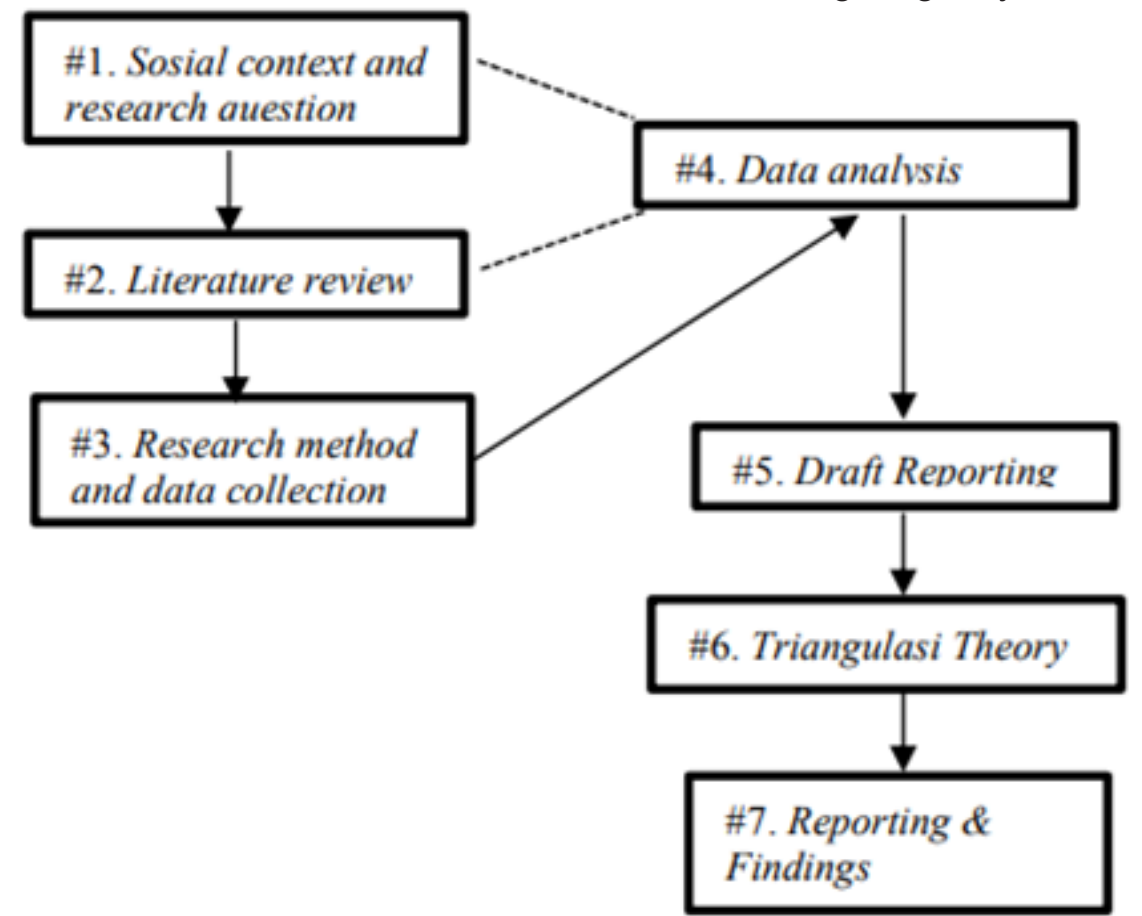

Figure 1.

Simple Design Model With Theory Triangulation / Simple Research Design With Triangulation Theory 
more precise at the Online Social gathering Organizers, Determination of informants in this study using a purposive method. According to (Arikunto, 2014) purposive is a technique of determining informants not based on regions or strata, but based on the existence of considerations that focus on certain objectives in this study. This research was conducted on online social gathering organizers in Jombang district who have at least held online social gathering for at least the last 5 years and are willing to be interviewed in-depth (Indepth Interview) to obtain valid, relevant and adequate information which is the answer to the problem being researched. One thing that is common in qualitative research is the change in the number of informants. Initially there were 10 informants who matched the criteria, there were 7 prospective informants who were not willing to be interviewed in-depth, so only 3 informants would become informants in this study.

\section{Informant Profile I}

The first informant is Maria, 30 years old and a housewife. The address of the first informant was in Candimulyo Village, Jombang District. The first informant running an online social gathering has been running for 5 years. The marketing strategy for segmentation, targeting, and positioning carried out by the first informant was to segment the market based on geography or area, namely the area of Jombang. And also do market segmentation based on demographics, namely segmentation by age. After determining the segmentation, the first informant carried out a targeting marketing strategy, namely the targets aimed at the first informant based on the minimum age of 17 years to the age of 40 who were in the Jombang area. The positioning strategy carried out by the first informant so that consumers will always remember it is by giving a give away to the consumer. Give away given in the form of money or bonuses and gold. The first informant not only opened the social gathering slot to get money, but also opened the social gathering slot for goods such as cellphones and cosmetics. In conducting this online social gathering, the first informant did marketing services through online media such as WhatsApp, Instagram and Facebook.

\section{Informant Profile II}

The second informant is Ratih, 23 years old and a student. The address of the second informant is in Pandanwangi Village, Diwek District, Jombang Regency. This second informant has been running an online social gathering for 5 years. The segmentation marketing strategy carried out by this second informant is segmentation based on geography or area, namely the Jombang area and segmentation based on demographics, namely segmentation based on age. After determining the segmentation, the target or target aimed by the second informant, starting from the age of 18 to the age of 40 years and already having an income and who is domiciled in the Jombang area. To get the position in the minds of consumers, this second informant does this by disbursing the get-gathering, there is no deduction for the admin, so that the get member gets completely without any deductions. The second informant is marketing online social gathering services using social media in the form of Instagram and WhatsApp.

\section{Informant Profile III}

The third informant is a 35 year old Sindy who is a housewife. The address of the third informant was in Kauman Mojoagung Jombang. The segmentation marketing strategy carried out by this third informant is segmentation based on demographics, namely by age. For region or geography, the third informant did not segment because according to the informant's opinion, the three people from various regions could follow the social gathering that the informant was holding. This 
third informant also segmented based on demographics, namely by age. After doing the segmentation, the target audience for this third informant is those who are already working and aged at least 18 years to 45 years from all regions. The third informant ran an online social gathering for 3 years. For the third informant's positioning marketing strategy, always trust and upload proof of transfer when disbursed. In addition, disbursements must be on time according to the agreement. The media used in the marketing of online social gathering services is through Facebook and WhatsApp. Researchers conducted indepth interviews with informants to dig up more information for some time by recording using cellphones, and there were several things that were asked by researchers but were not attached to in-depth interview evidence because they did not include indepth interview evidence. The following is a breakdown of the in-depth interviews the researchers conducted in October 2020.

\section{RESULTS AND DISCUSSION Product}

In this study, the products offered by the three informants were money social gathering products, goods social gathering in the form of cellphones and cosmetics social gathering. then the products offered by the owner to consumers are as follows

“... social gathering money, social gathering for goods (handphone), social gathering for cosmetics ..." (Maria)

In the opinion of the informant Maria, holding an social gathering does not only have to be a cash social gathering, it can also open an social gathering slot for items such as cellphones and cosmetics to make it more varied. Currently, there are so many that only hold money gathering.

"... the money social gathering ..." (Ratih)
According to the informant's opinion, Ratih is still holding money gathering. When members attend this social gathering it is the same as saving money. And most of the consumers are more interested in money gathering than non-money social gathering.

$$
\text { “... social gathering money ...” (Sindy) }
$$

Meanwhile, according to the informant, Sindy is more comfortable holding a money social gathering than other social gathering. When holding a social gathering, the profit is greater than that of a social gathering other than money.

From this explanation, it can be said that they have the same product, namely social gathering. The products offered generate reactions and consumer interest in being noticed, owned, used or consumed so as to satisfy consumer wants and needs. The products offered by the owner to consumers also vary.

\section{Price}

As stated by the three informants, the prices for the products offered to consumers are as follows:

“... prices or get start from 500,000 to 10,000,000 ..." (Maria)

According to Maria's informant, the various slots opened there are those that open the lowest get of 500,000 every two weeks. And the highest gets 10,000,000 every month. So that consumers can choose to follow the slots according to their needs and desires.

“...get starts from 500,000 to $15,000,000$ ..." (Ratih)

According to the informant Ratih, the existing social gathering slots vary from once a week, once in 15 days or once a month with a get of 500,000 to get $15,000,000$ every once a month. so that 
consumers can choose to participate in a long or short term social gathering. And according to the consumer's ability to pay for social gathering and the needs of each consumer.

"... some start from the lowest get $1,000,000$ to get $20,000,000$..." (Sindy)

According to the informant, Sindy held an social gathering with the lowest slots starting from get $1,000,000$ to get $20,000,000$ every month. Consumers can choose slots according to the income of the consumers themselves.

Price is very influential on consumer purchasing decisions. The price offered by the owner of this online social gathering is in accordance with the get that the consumer wants to get, so that the consumer chooses the get the social gathering slot according to his wishes.

\section{Online Marketing}

In marketing social gathering products through social media, namely using social media WhatsApp, Facebook, and Instagram. In this study, the informant used by the researcher was the owner of the social gathering in Jombang who used online media.

\section{Online Social gathering}

In building a service marketing strategy, the three informants have a difference that is considered to be able to attract consumers to take part in the online social gathering they are holding. The service marketing strategy carried out by the owner in running online social gathering according to the three informants is very important. The strategy they are doing is useful for developing an online social gathering that is run so that it focuses more on the targets or goals that have been determined by the online social gathering owner.
The service marketing strategy used by online social gathering owners in running an online social gathering business based on the results of interviews with informants shows that all informants are almost the same in using service marketing strategies, namely segmenting, targeting, and positioning marketing strategies and for finding members or consumers through online media such as media. whatsapp, facebook and instagram. Informants stated that using online media was more effective in reaching wider consumers and offering their products.

\section{Marketing strategy Segmenting, Targeting and Positioning (STP)}

In this research, the product offered is a social gathering. Because the owner of this online social gathering benefits in the form of having a relationship with many people and also benefits from holding an online social gathering. The following is the market segmentation according to the three informants:

"... the segment for now is still in the Jombang area ..." (Maria)

For now, according to the informant Maria, the segment chosen is a segment based on geography or region. The selected area segment is the Jombang area.

"... the segmentation for the areas that I still reach is only those in the Jombang area ..." (Ratih)

According to the informant Ratih, the area segment currently covered is still in the Jombang area. Still not outside Jombang. From Nawang's opinion, it was explained that the selected segmentation was segmentation based on geography or area.

“... I didn't do segmentation because it could be followed by people from vari- 
ous regions ..." (Sindy)

According to the opinion of the Sindy informant, the online social gathering that is run can be followed by people from various regions, not only the Jombang area. However, many of them participated in this social gathering in the Jombang area.

From the three informants above that segmentation is needed to be able to focus on where we will offer our products. After doing segmentation, the second marketing strategy is to determine the target or target consumers. Determination of targets or target consumers carried out by the three informants as follows:

"... the target is from the age of 17 to

40 years. and have their own income ..." "Maria)

Maria's informants target consumers who are at least 17 years old up to 40 years old. According to the informants who participated had identification cards such as KTP. If those who want to join are 17 years old but don't have a KTP, they can show their family card.

"... at least 18 years to 40 years of age and those who already have their own income ..." (Ratih)

For this social gathering, it starts from a minimum age of 18 years to 40 years and has an income. If you want to take part in this social gathering, you must also have the consent of your parents or husband.

“... the targets are already working or have their own income. Starting from the age of 18 years to 45 years .. "(Sindy)

For consumers the Sindy informant addresses are those who already have income. And those who are at least from the age of 18 years to the age of 45 years. And also must have a KTP.

According to Rangkuti, (2013), targeting is the process of evaluating the attractiveness of each market segment and selecting one market segment to enter. The existence of a good target market determination will make it easier for companies to allocate their products to consumers.

After finishing determining the market segmentation and target market, the social gathering owner must also position the social gathering owner to the minds of consumers. This positioning is a marketing strategy in stage three. Positioning in the context of marketing is how a product, brand, or company organization is perceived relative to competitors' products, brands or organizations by other customers or potential customers. According to Rangkuti, (2013), positioning is the activity of designing, offering, and creating the best possible company image or product / service image, so that it is able to occupy a good and different competitive position in its target customers. The following determines the position of consumers according to the three informants:

"... by giving a give away to the members. Besides that, it doesn't just hold a money gathering ... "(Maria)

According to the informant, Maria positions her social gathering products in the minds of consumers by often giving away to members. This give away is by lottery. The give away can be in the form of money or bonuses and gold. When participating in an social gathering slot, besides getting money, it can also be requested in the form of money or goods held in the social gathering slot.

"... when disbursing there is no deduction, so the money you get is full ..." (Ratih)

According to Ratih, to give the position of the social gathering products to 
consumers by providing a full social gathering without any admin deductions. When in circulation online, most of them will make a deduction when it is disbursed.

“... make disbursements on time according to the agreement between the owner and members. Uploading proof of transfer when disbursing and always trustworthy ... "(Sindy)

According to Sindy, by holding this online social gathering, you must always be trusted to gain the trust of consumers. Not only that, when making disbursements, you must include proof of transfer. Before disbursing members will be notified how much and if there is a discount. That was explained beforehand so that there is no misunderstanding between the members and the owner of the social gathering . And always be on time when making disbursements according to the agreement between the member and owner.

\section{Marketing of Services through Online Media}

The three social media informants used are: The media used to do the marketing of this social gathering service is through the social media WhatsApp, Instagram and Facebook. However, focus more on using whatsapp and grub media for every batch also on whatsapp.

“... via WhatsApp, and Instagram ..." (Ratih)

For social media, the informant Ratih uses the WhatsApp media for grub for every social gathering group. Meanwhile, Instagram social media is used to upload every time you make a withdrawal and also promote an empty social gathering slot. “... via WhatsApp and Facebook ...”
(Sindy)

According to the informant, the me- dia used to promote this social gathering was whatsapp and facebook media. Both of these media can reach more consumers. Because most people use WhatsApp and Facebook more often. And also promoting social gathering via Facebook is faster to get consumers than using Instagram media.

\section{Triangulation Theory \\ Marketing Strategy}

According to Alma, (1998) states that a marketing strategy is to choose and analyze a target market which is something to be achieved and to create a marketing mix that is suitable and can satisfy certain target markets. In carrying out the marketing strategy there are three steps used according to the theory of Kotler and Armstrong, (2010), namely segmenting, targeting and positioning or commonly referred to as STP. The first is market segmentation, which is the process of classifying a heterogeneous whole market into groups or segments that have similarities in terms of needs, wants, behavior and responses to specific marketing programs (Tjiptono, 2008).

In building a service marketing strategy, the three informants have a difference that is considered to be able to attract consumers to take part in the online arisan they are holding. The service marketing strategy carried out by the owner in running online social gathering according to the three informants is very important. The strategy they are doing is useful for developing online social gathering that is run so that it focuses more on the targets or goals that have been determined by the owner of the online arisan according to Alma, (1998: 195) which states that the marketing strategy is to choose and analyze the target market which is something to be achieved and create a marketing mix that is suitable and can satisfy certain target markets. In carrying out the marketing strategy, there are three steps used according to the theory of 
Tjiptono \& Chandra, (2012), namely segmenting, targeting and positioning or commonly referred to as STP. In this research, the product offered is a social gathering. Because the owner of this online arisan benefits in the form of having a relationship with many people and also benefits from holding an online arisan.

According to Wright et al., (2006: 5) service marketing theory, service is an action or performance that creates benefits for customers by realizing the desired changes in the recipient's self or name. In marketing arisan products through social media, namely using social media WhatsApp, Facebook, and Instagram according to theory (Michael Cross, 2013) social media is a term that describes the various technologies used to bind people into a collaboration, mutually exchange information, and interact through web-based message content. In this study, the informant used by the researcher was the owner of the arisan in Jombang who used online media.

The service marketing strategy used by online social gathering owners in running an online arisan business based on the results of interviews with informants shows that all informants are almost the same in using service marketing strategies, namely segmenting, targeting, and positioning marketing strategies and for finding members or consumers through online media such as media. whatsapp, facebook and instagram. Informants stated that using online media was more effective in reaching wider consumers and offering their products..

\section{Product}

In this study, the products offered by the three informants were money social gathering products, goods arisan in the form of cellphones and cosmetics social gathering. A product is a combination of goods and services that a company offers to its target market. According to (Kotler \& Keller, 2009), it is anything that can be of- fered to the market to get attention, buy it for use, or consume it that can satisfy a desire or need.

The products offered generate reactions and consumer interest in being noticed, owned, used or consumed so as to satisfy consumer wants and needs. The products offered by the owner to consumers also vary.

\section{Price}

According to Kotler \& Armstrong,( 2012): 345) price can be defined narrowly as the amount of money billed for a product or service or can be defined broadly as the amount of value that consumers exchange for the benefit of owning and using a product or service that allows the company to get a profit that is fair by being paid for the customer value it creates, price is one element of the marketing mix that generates revenue, another element generates costs.

Price is very influential on consumer purchasing decisions. The price offered by the owner of this online social gathering is in accordance with the get that the consumer wants to get, so that the consumer chooses the get the social gathering slot according to his wishes.

\section{Marketing of Services through Online Media}

Social Media is a term that describes various technologies used to bind people into collaboration, exchange information, and interact through web-based message content. Because the internet is always developing, the various technologies and features available to users are always changing (Michael Cross, 2013).

The media used to promote this social gathering uses the WhatsApp, Instagram and Facebook media. These three media can reach more consumers. Because most people use WhatsApp and Instagram, Facebook more often. And also promoting arisan through these three media is faster to get consumers. The results 
of this study are in accordance with Rosdianti, (2018) entitled marketing strategy of the Watang Sawitto Islamic pawnshop marketing strategy in Pinrang Regency. The results show that the marketing strategy of the precious metal social gathering which is carried out by the Watang Sawito Islamic pawnshop in Pinrang Regency in increasing the number of customers by using a marketing mix system and SWOT analysis.

\section{Findings}

In running an online social gathering service business, it turns out that the informants convey that it is not enough just to run a business in accordance with the existing provisions without involving the mandate in it. Amanah has an important role in individual interpersonal relationships. Mandate attitudes and behaviors are able to form positive relationships be-

\section{CONCLUSIONS}

The online marketing strategy for social gathering services will be able to survive if it is supported by the products offered, causing reactions and consumer interest to be noticed, owned, used or consumed so as to satisfy the desires and needs of consumers. The products offered by the owner to consumers also vary. The price offered by the owner of the online arisan is in accordance with the get that consumers want to get, so that consumers choose the get the social gathering slot according to their wishes, the use of online media is more effective to reach wider consumers and offer their products. The owner of this online arisan benefits in the form of having a relationship with many people and also benefits from holding an online social gathering, the most important finding of this research is to include the mandate in running an online arisan service business.

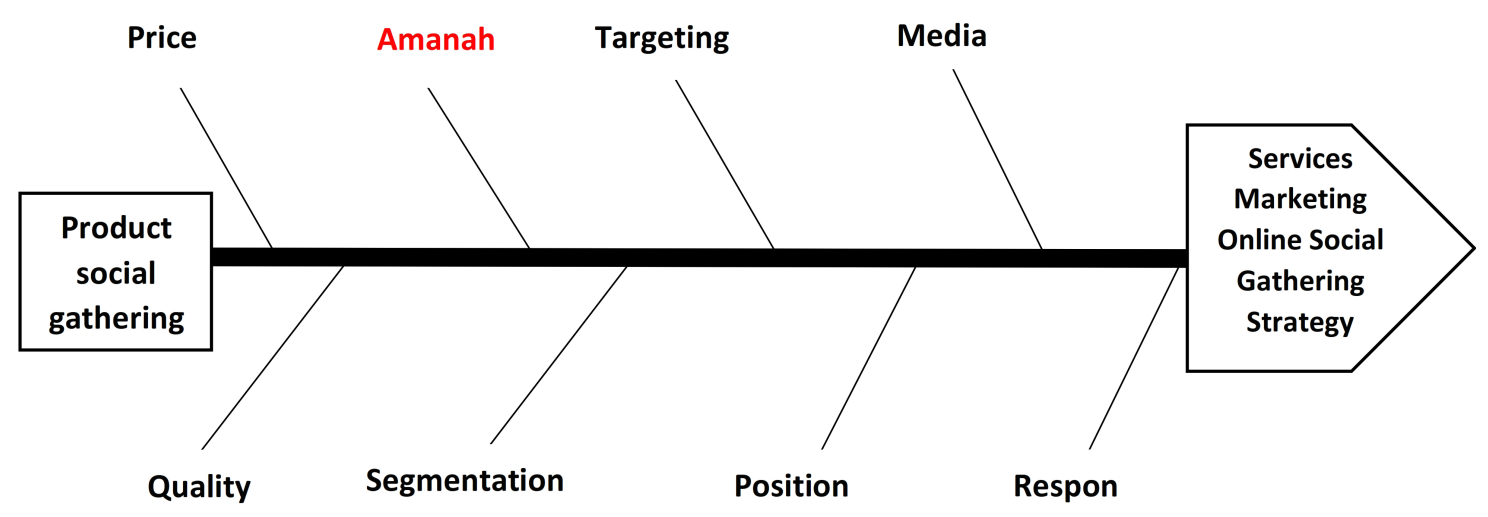

Figure 2.

Findings of Online Arisan Services Marketing Strategy

tween individuals and groups. According to Hamka, (1990) mandate is a basic foundation in social and state life. Amanah is a social glue in building solidarity in society which aims to form cooperation among Pulungan individuals, (2006). Without a mandate, the life of the community and the state will be damaged. For example, a lot of criminal behavior or conflict is caused because there is no mandate in carrying out duties and behaving according to Ibnu Katsir (2013).

\section{REFERENCE}

Alma, B. (1998). Manajemen Pemasaran dan Pemasaran Jasa, Edisi Kedua. CV "Alfabeta". Bandung.

Arikunto, S. (2014). Metode penelitian kuantitatif, kualitatif, dan kombinasi (mixed methods). Bandung: Alfabeta.

Badriyah, L. (2015). Perlindungan hukum bagi peserta arisan haji dan umrah: Study kasus di KBIH Al-Kautsar Dusun Dempok Desa Grogol Kecamatan Di- 
wek Kabupaten Jombang. Universitas Islam Negeri Maulana Malik Ibrahim.

Bungin, B. (2020). Post-Qualitative Social Research Methods. Kencana.

Kharisma, B., Remi, S. S., Hadiyanto, F., \& Saputra, A. D. (2020). The Economics of Rotating Savings and Credit Associations (ROSCAs) and Poverty in Indonesia. Jurnal Economia, 16(1), 100-111.

Khoiriyah, N. N. (2018). Pandangan tokoh Majelis Ulama Indonesia (MUI) Kabupaten Ponorogo terhadap tradisi arisan sembako untuk acara hajatan: Studi di Desa Sooko Kecamatan Sooko Kabupaten Ponorogo. Universitas Islam Negeri Maulana Malik Ibrahim.

Kotler, P., \& Armstrong, G. (2012). Principles of marketing 14th edition. New Jearsey: Pearson Education Inc, 67.

Kotler, P., \& Keller, K. L. (2009). Dirección de marketing. Pearson educación.

Masithah, S. (2018). Tinjauan Hukum Islam Tentang Pelaksanaan Arisan Online Handphone Di Instagram (Studi Pada Pemilik Akun Instagram@ tikashop_ bdl). UIN Raden Intan Lampung.

Michael Cross. (2013). Social Media. Universitas Islam Negeri Surabaya.

Mukarromah, I. D. (2021). Tindak Pidana Penipuan Melalui Online Dalam Kegiatan Arisan Berdasarkan Pasal 378 Kitab Undang-Undang Hukum Pidana. Dinamika: Jurnal IImiah IImu Hukum, 27(1), 24-33.

Pribadi, A. (2020). Arisan Qurban Di Mushola Al-Muttaqin 25 B Margodadi Metro Selatan Kota Metro Perspektif Hukum Ekonomi Syariah. IAIN Metro.

Ramadhita, R., \& Khoiriyah, I. R. (2020). Akad arisan online: antara tolong menolong dan riba? Al-Mashlahah Jurnal Hukum Islam Dan Pranata Sosial, 8(1),
25-42.

Rangkuti, F. (2013). Strategi promosi yang kreatif dan analisis kasus. Gramedia Pustaka Utama.

Ria, E. (2019). Tinjauan Hukum Islam Tentang Arisan Emas Batangan. UIN Raden Intan Lampung.

Rofiah, C. (2021). QUALITATIVE METHODS: SIMPLE RESEARCH WITH TRIANGULATION THEORY DESIGN. Develop, 5(1), 18-28.

Rosdianti, R. (2018). Strategi Pemasaran Arisan Logam Mulia Pegadaian Syariah Watang Sawitto Kabupaten Pinrang. IAIN Parepare.

Sarmalina, S., Sarmadi, S., Rahmi, M., \& Mangunsong, S. (2019). Peningkatan Kapasitas Ibu-Ibu Arisan Sebagai Inisiator Gerakan Masyarakat Cerdas Menggunakan Obat (Gema Cermat). LINK, 15(1), 36-41.

Susila, D. (2015). Analisis Yurldis Tentang Perjanjian Arisan Kendaraan Bermotor Di Kabupaten Klaten.

Tjiptono, F., \& Chandra, G. (2012). Pemasaran Strategik, Edisi 2, Yogyakarta, CV. Andi Offset.

Tjiptono Fandy. (2008). Pemasaran Strategik. Andi Publisher; Yogyakarta;

Umar, M. Z. (2017). Pembangunan Rumah Tinggal dengan Sistim Arisan di Desa Pangan Jaya. EMARA Indonesian Journal of Architecture, 3(1), 1-9.

Wright, J. L., Lovelock, D. M., Bilsky, M. H., Toner, S., Zatcky, J., \& Yamada, Y. (2006). Clinical outcomes after reirradiation of paraspinal tumors. American Journal of Clinical Oncology, 29(5), 495-502.

Yin, R. K. (2013). Studi kasus: Desain \& metode. jakarta: PT Rajagrafindo Persada. Jakarta. 
Yudha, I. B. N. K., \& Rudy, I. D. G. (2015).

Tanggung Jawab Ketua dalam Penyelenggaraan Arisan Ditinjau dari Hukum Perjanjian. Kertha Semaya: Journal Ilmu Hukum, 4(1).

Yusanto, M. I. (2002). Menggagas Bisnis Islami. Gema Insani. 